\title{
EVALUASI SISTEM DAN PROSEDUR PEMBENTUKAN SERTA PENGGUNAAN UANG PERSEDIAAN PADA KANTOR BAPELITBANGDA KOTA MANADO
}

\author{
Yurike Sella Pido ${ }^{1}$, Jantje Tinangon ${ }^{2}$, Sherly Pinatik ${ }^{3}$ \\ ${ }^{1}$ Jurusan Akuntansi, Fakultas Ekonomi dan Bisnis, Universitas Sam Ratulangi, Jl. Kampus Unsrat, Kota \\ Manado, 95115, Indonesia \\ E-mail : 'yurikesellapido@gmail.com
}

\begin{abstract}
Inventory money is cash in hand of expense treasurer, this fund is given once in one budget year and is revolving. The amount of Inventory Money depends on local policy. Systems and Procedures used in the Establishment and Use of Inventory Money need to be assessed so it can be known whether it is in accordance with Permendagri No.13 / 2006 which then revised to Permendagri No.21 / 2011 on Management of Regional Financial Guidance. The purpose of this study is to evaluate whether the System and Procedure of Establishment and Use of Inventory at the BAPELITBANGDA office of Manado city is in accordance with the applicable Regulations. The research method used is descriptive which gives a systematic, factual, accurate description of the problem under investigation. The result of the research shows that BAPELITBANGDA Manado has implemented System and Procedure effectively in accordance with Permendagri No .13 / 2006 and the second amendment of Permendagri No.21/2011
\end{abstract}

Keywords: funds inventory money, systems and procedures, evaluation

\section{PENDAHULUAN}

Kehidupan di era globalisasi ini begitu banyak perkembangan di setiap bidangbidang yang mempengaruhi berbagai aspek kehidupan, bukan hanya bagi pemerintah tetapi juga bagi perusahaan ataupun organisasi publik lainnya yang bersangkutan dengan aspek kehidupan yang ada. Di setiap wilayah atau kota mempunyai publiknya masing-masing dengan keluasannya tidak hanya disebabkan oleh luasnya jenis dan bentuk organisasi yang ada di dalam wilayah atau kota tersebut. Akan tetapi juga dipengaruhi oleh kompleksnya lingkungan di sekitarnya, diantaranya yaitu ekonomi, politik sosial, budaya dan historis.

Saat ini di setiap negara pasti membutuhkan pemerintahan yang baik atau yang biasa disebut Good Governance, termasuk di Indonesia. Pemerintah daerah diwajibkan menyusun laporan pertanggungjawaban yang menggunakan sistem akuntansi yang diatur oleh pemerintah pusat dalam bentuk Undang-undang dan Peraturan Pemerintah yang bersifat mengikat seluruh Pemerintah Daerah yang bertujuan untuk meningkatkan akuntabilitas dan transparansi dalam pengelolaan keuangan pemerintah daerah.

Upaya konkrit untuk mewujudkan transparansi dan akuntabilitas pengelolaan keuangan daerah adalah penyampaian laporan pertanggungjawaban keuangan pemerintah yang memenuhi prinsip tepat waktu serta dapat diandalkan dan disusun dengan mengikui Standar Akuntansi Pemerintahan (SAP) yang telah diterima secara umum. Permendagri Nomor 13 tahun 2006 dan perubahan keduanya Permendagri Nomor 21 Tahun 2011 tentang Pedoman Pengelolaan Keuangan Daerah, mengamanatkan bahwa Menteri dalam negeri melakukan pembinaan dan pengawasan pengelolaan keuangan daerah kepada pemerintah daerah antara lain pemberian dokumen sistem dan prosedur pengelolaan keuangan daerah.

Di setiap SKPD dalam menjalankaan kegiatan operasionalnya membutuhkan dana untuk membiayai setiap pengeluaran - pengeluaran baik yang bersifat besar maupun kecil, di antaranya dana uang persediaan yang merupakan uang kas yang ada di tangan bendahara 
pengeluaran, hanya diberikan sekali dalam satu tahun anggaran yang bersifat revolving (adanya pengisian kembali jika telah terpakai) besarannya tergantung pada "kebijakan daerah" (biasanya dinyatakan dalam Surat Keputusan Kepala Daerah).

Berdasarkan uraian yang dikemukakan di atas maka perlu melakukan evaluasi sistem dan prosedur pembentukan serta penggunaan uang persediaan pada Pemerintah kota Manado khususnya dalam hal pembentukan serta penggunaan uang persediaan (UP) yang dilakukan oleh kantor BAPELITBANGDA kota Manado yang dituangkan dalam bentuk skripsi dengan judul Evaluasi Sistem dan Prosedur Pembentukan serta Penggunaan Uang Persediaan Pada Kantor BAPELITBANGDA kota Manado.

\section{TINJAUAN PUSTAKA}

\subsection{Pengelolaan Keuangan Daerah}

Ratmono dan Sholihin (2015:6), mendefinisikan bahwa pengelolaan keuangan daerah adalah seluruh kegiatan yang meliputi perencanan, pelaksanaan, penatausahaan, pelaporan, pertanggung jawaban, dan pengawasan keuangan daereah. Peran penting akuntansi bagi pemda ditunjukkan dalam pasal 51 UU No 17 tahun 2003 yaitu setiap Pejabat Pengelola Keuangan Daerah selaku Bendahara Umum Daerah dan Kelapa Satuan Kerja Perangkat Daerah selaku pengguna anggaran harus menyelenggarakan akuntansi atas transaksi keuangan, aset, utang, dan ekuitas, termasuk transaksi pendapatan belanja dan pembiyaan yang berada dalam tanggung jawabnya.

\subsection{Sistem Pengendalian Internal}

Mulyadi (2014 : 163), sistem pengendalian interal didefinisikan sebagai berikut : "Sistem pengendalian intern meliputi struktur organisasi, metode dan ukuran-ukuran yang dikoordinasikan untuk menjaga kekayaan organisasi, mengecek ketelitian dan keandalan data akuntansi, mendorong efisiensi dan mendorong terjadinya kebijakan manajemen. Definisi sistem pengendalian intern tersebut menekankan tujuan yang hendak dicapai, dan bukan pada unsur-unsur yang membentuk sistem tersebut, dengan demikian pengertian pengendalian intern tersebut diatas berlaku baik dalam perusahaan yang engolah informasinya secara manual, dengan mesin pembukuan, maupun dengan komputer.

\subsection{Akuntansi Pemerinthan di Indonesia}

Tahun 1991 merupakan saat mulanya perkembangan dalam bidang akuntansi pemerintah dengan keputusan mentri keuangan Republik Indonesia No 476/KMK/01/1991. Tanggal 21 Mei 1999 tentang sistem akuntansi pemerintah pusat telah ditetapkan secara resmi hal-hal yang berkenaan dengan pelaksanaan akuntansi pemerintah.

Perkembangan yang menyangkut masalah tersebut adalah semakin meningkatnya tugas pemerintah dalam kegiatan pembangunan yang membawa transaksi pemerintah semakin meningkat. Praktek sistem akuntansi pemerintah dikembangkan bukan untuk memenuhi tujuan pertanggungjawaban saja, tetapi juga harus dapat menyediakan informasi keuangan yang dibutuhkan untuk perencanan, penggarapan, pelaksanaan, pemantauan, pengendalian anggaran, evaluasi pelaksanaan serta untuk perumusan kebijaksanaan dan pengambilan keputusan.

\subsection{Sistem dan Prosedur Pembentukan serta Penggunaan Uang Persediaan}

Uang persediaan (UP) adalah istilah baru yang muncul dalam Permendagri No.13 / 2006 yang kemudiaan direvisi menjadi Permendagri No. 21 / 2011 tentang Pedoman Pengelolaan Keuangan Daerah. UP merupakan uang kas yang ada di tangan bendahara pengeluaran, dengan karakteristik sebagai berikut :

1. Hanya diberikan sekali dalam satu tahun anggaran;

2. Diberikan pada awal tahun anggaran; 
3. Merupakan jumlah maksimal (pagu) uang yang dipegang oleh bendahara pengeluaran;

4. Untuk digunakan dalam melaksanakan pembayaran kegiatan-kegiatan yang bersifat swakelola;

5. Bersifat revolving (adanya pengisian kembali jika telah terpakai)

6. Besarannya tergantung pada "kebijakan daerah" (biasanya dinyatakan dalam Surat Keputusan Kepala Daerah).

Permendagri 21 / 2011 memperkenalkan mekanisme Uang Persediaan dalam prosedur pengelolaan uang yang dilakukan oleh SKPD. Berikut adalah beberapa pointernya :

1. Konsep

Uang Persediaan merupakan uang muka kerja SKPD yang bersifat revolving. Definisi ini merupakan implikasi dari dipilihnya sistem UYHD, sebuah sistem yang mengadopsi sistem Imprest Fund dalam pengelolaan kas kecil. Dengan sistem tersebut, bendahara sebagai pengelola kas diberikan uang muka kerja pada besaran tertentu, untuk kemudian dipakai untuk membiayai kegiatan SKPD, dan jika jumlah telah berkurang sampai batas tertentu dapat dimintakan penggantian sehingga jumlah uang akan kembali pada nilai semula.

2. Dokumen

Mekanisme uang persediaan menggunakan dokumen sebagai berikut:

a. SPD (Surat Penyediaan Dana)

b. SPP UP (Surat Perintah Pembayaran Uang Persediaan)

c. SPM UP ( Surat Perintah Membayar Uang Persediaan)

d. SP2D (Surat Perintah Pencairan Dana)

e. SPJ (Surat Pertanggungjawaban)

3. Isu Lapangan

Isu lapangan diantaranya: .

1. Bagi Kas Daerah, UP merupakan pengeluran. Bagi SKPD, merupakan penerimaan. Namun dalam sudut pandang Pemda, UP hanya merupakan reklasifikasi kas semata. Jadi, dokumen penatausahaan tidak perlu mencantumkan kode rekening belanja yang menandakan adanya pembebanan belanja APBD.

2. Penggantian UP yang telah digunakan menggunakan GU. Penggantian tersebut tidak dipicu berdasarkan waktu, tetapi dipicu berdasarkan kondisi (jumlah) keberadaan UP itu sendiri. Dengan demikian permintaan GU tidak harus menunggu sebulan atau periode waktu tertentu, namun tergantung pada kebutuhan.

Uang Persediaan (UP) dapat digunakan untuk pengeluaran :

a. Belanja Barang dan Jasa

b. Belanja lain-lain

Uang Persediaan digunakan untuk keperluaan membiayai kegiataan operasional Sehari-hari SKPD dan membiayai pengeluaran yang tidak dapat dilakukan melalui mekanisme LS, yang dimaksud dengan mekanisme pembayaran LS adalah lebih mengarah kepada sifat praktis pelaksaan pembayaran, misalnya SKPD mau melaksanakan pembeliaan maubel sebesar Rp. 1.000.000 lalu disampaikan ke toko yang mau menjual, bahwa pembayaran akan dilaksanakan dengan cara pembayaran LS dan harus melalui proses ini, itu, selama misalnya 5 hari baru dibayar, maka kemungkinan besar toko tersebut akan menolak. Sehingga SKPD harus mencari lain lagi. Hal ini tentu lebih praktis jika pembayaraan dilaksanakan melalui Uang Persediaan. 


\section{METODE PENELITIAN}

\subsection{Jenis Penelitian}

Jenis penelitian yang digunakan adalah penelitian kualitatif. Menurut pendapat beberapa ahli dalam Moeleong, 2013 : 4 - 6 salah satunya menurut Kirk dan Miller penelitian kualitatif adalah tradisi tertentu dalam ilmu pengetahuan sosial yang secara fundamental bergantung dari pengamatan pada manusia baik dalam kawasannya maupun dalam peristilahannya

\subsection{Metode Pengumpulan Data Jenis Data}

Sugiyono (2013:28), mengemukakan bahwa data penelitian dapat dikelompokan menjadi dua jenis yaitu :

1. Data Kualitatif yang merupakan data berbentuk kata, kalimat, gerak tubuh, ekspresi wajah, bagan, gambar, dan foto.

2. Data Kuantitatif yang merupakan data yang berbentuk angka atau data kualitatif yang di angkakan (scoring).

Jenis data yang digunakan dalam penelitian ini adalah data kualitatif yakni data yang disajikan secara deskriptif dalam bentuk uraian, seperti gambaran kantor, kegiaatan operasional, serta data kepustakaan.

\section{Sumber Data} dua yaitu :

Sugiyono (2013 : 223), menyatakan bahwa sumber data penelitian terbagi menjadi

1. Data primer yang merupakan sumber data yang langsung memberikan data kepada pengumpul data.

2. Data sekunder yang merupakan sumber data yang tidak langsung memberikan data kepada pengumpul data, misalnya hanya melalui dokumen.

Sumber data yang digunakan dalam penelitian ini adalah data primer, data yang diperoleh langsung dari objek penelitian.

\subsection{Teknik Pengumpulan Data}

Menurut Sugiyono (20013 : 62) Teknik pengumpulan data merupakan langkah yang paling strategis dalam penelitian, karena tujuan utama dari penelitian adalah mendapatkan data. Menurut Maryadi dkk (2013 : 14) Teknik pengumpulan data yang digunakan dalam penelitian Kualitatif adalah teknik yang memungkinkan diperoleh data detail dengan waktu yang relatif lama. Teknik pengumpulan data yang dilakukan dalam penelitian ini adalah teknik wawancara, teknik observasi dan dokumentasi.

\section{Teknik wawancara}

Proses komunikasi atau interaksi untuk mengumpulkan informasi dengan cara tanya jawab antara peneliti dengan informan atau subjek peneliti. Pada hakikatnya wawancara merupakan kegiatan untuk memperoleh informasi secara mendalam tentang sebuah tema yang diangkat dalam sebuah penelitian. Tahapan yang peneliti lakukan untuk melakukan wawancara yaitu :

a. Peneliti mencari tau kondisi lapangan penelitian yang sebenarnya untuk mempermudah dalam merencanakan pengambilan data.

b. Peneliti menyusun protokol wawancara.

c. Berdasarkan persiapan pada bagian pertama dan kedua maka peneliti menyusun strategi pengumpulan data secara keseluruhan.

2. Teknik observasi

Penulis melakukan pengamatan dan pencatatan langsung kelapangan terhadap setiap kajian yang menjadi objek. Observasi hakikatnya merupakan kegiatan dengan menggunakan pancaindera, bisa penglihatan, penciuman, pendengaran, untuk memperoleh informasi yang diperlukan untuk menjawab masalah penelitian. 


\section{Dokumentasi}

Selain melalui wawancara dan observasi, informasi juga bisa diperoleh lewat fakta yang tersimpan dalam bentuk surat, catatan harian, arsip foto, hasil rapat, jurnal kegiatan dan sebagainya. Data berupa dokumen seperti ini bisa dipakai untuk menggali informasi yang terjadi dimasa yang sudah lewat.

\subsection{Metode Analisis}

Penelitian ini dilakukan bersifat studi deskriptif yang memberikan gambaran secara sistematis, faktual dan akurat mengenai masalah yang diselidiki.Penelitian deskriptif merupakan penelitian terhadap masalah-masalah berupa fakta -fakta saat ini dari suatu populasi. Studi deskriptif dilakukan dengan cara mendeskripsikan masalah yang telah didefinisikan dan terbatas pada usaha untuk mengungkapkan masalah serta keadaan sebagaimana adanya. Tujuannya adalah untuk membuat suatu deskripsi situasi-situasi dan kejadian-kejadian tertentu, sehingga tidak perlu mencari atau megembangkan keterkaitan antar variable atau menguji hipotesis.

\section{HASIL PENELITIAN DAN PEMBAHASAN}

\subsection{Hasil Penelitian}

Dari hasil wawancara dan observasi yang dilakukan dapat di jelaskan sistem dan prosedur pembentukan serta penggunaan uang persediaan ( UP ) pada BAPELITBANGDA kota Manado adalah :

\section{Pembentukan Uang Persediaan (UP) :}

\section{Penerbitan Surat Penyediaan Dana ( SPD )}

SPD merupakan Surat Penyediaan Dana, yang dibuat oleh Bendahara Umum Daerah rangka manajemen kas daerah. dokumen ini menyatakan tersedianya dana untuk melaksanakan kegiatan sebagai dasar penerbitan SPP.

2. Pengajuan Surat Permintaan Pembayaran ( SPP UP )

SPP UP adalah dokumen yang diajukan oleh bendahara pengeluaran untuk permintaan uang muka kerja yang bersifat revolving (adanya pengisihan kembali jika telah tepakai) dipergunakan untuk mengisi uang persediaan tiap - tiap SKPD. Pengajuan SPP UP hanya dilakukan sekali dalam setahun pada awal tahun anggaran. Prosedur pengajuan SPP UP yaitu :

a. Pengguna Anggaran menyerahkan SPD kepada Bendahara dan PPK (Pejabat Penatausahaan Keuangan) SKPD.

b. Berdasarkan SPD, Bendahara membuat SPP UP beserta dokumen lainnya, yang terdiri dari Surat Pengantar SPP UP, Ringkasan SPP UP, Rincian SPP UP, Salinan SPD, Draft Surat Pernyataan untuk ditandatangani oleh Pengguna Anggaran / Kuasa Pengguna Anggaran yang menyatakan bahwa uang yang diminta tidak dipergunakan untuk keperluan selain uang persediaan, Lampiran lain ( daftar rincian rencana penggunaan dana sampai dengan jenis belanja ).

c. Bendahara menyerahkan SPP UP beserta dokumen lain kepada PPK ( Pejabat Penatausahaan Keuangan ) SKPD.

d. PPK ( Pejabat Penatausahaan Keuangan ) SKPD meneliti kelengkapan dokumen SPP UP dan kesesuaiannya dengan SPD dan DPA ( Dokumen Pelaksanaan Anggaran ) SKPD.

e. SPP UP yang dinyatakan lengkap akan dibuatkan Rancangan SPM oleh PPK SKPD. Penerbitan SPM paling lambat 2 hari kerja sejak SPP UP diterima

f. Rancangan SPM ini kemudian diberikan PPK SKPD kepada Pengguna Anggaran untuk diotorisasi

g. Jika SPP UP dinyatakan tidak lengkap, PPK SKPD akan menerbitkan Surat Penolakan SPM. Penolakan SPM paling lambat 1 hari kerja sejak SPP UP diterima 
h. Surat Penolakan Penerbitan SPM diberikan kepada Bendahara agar Bendahara melakukan penyempurnaan SPP UP. Kemudian diserahkan kepada PPK SKPD untuk diteliti kembali.

3. Penerbitan Surat Perintah Membayar ( SPM UP)

Dokumen yang diterbitkan oleh pengguna anggaran / kuasa pengguna anggaran untuk penerbitan SP2D atas beban - beban pengeluaran DPA SKPD yang dipergunakan sebagai Uang Persediaan untuk mendanai kegiatan. Proses penerbitan SPM merupakan tahapan penting untuk penatausahaan pengeluaran yang merupakan tahap lanjutan dari proses pengajuan SPP. Proses ini dimulai dengan pengujian atas SPM yang diajukan baik dari segi kelengkapan dokumen maupun kebenaran pengisiannya. SPM dapat diterbitkan jika pengeluaran yang diminta tidak melebihi pagu anggaran yang tersedia dan didukung dengan kelengkapan dokumen sesuai peraturan perundangan.

4. Penerbitan Surat Perintah Pencairan Dana ( SP2D )

Surat Perintah Pencairan Dana ( SP2D ) merupakan dokumen yang diterbitkan oleh kuasa Bendahara Umum Daerah setelah kuasa BUD meneliti kelengkapan dokumen SPM yang diajukan oleh pengguna anggaran / kuasa pengguna anggaran atau SP2D adalah surat yang dipergunakan untuk mencairkan dana lewat bank yang ditunjuk setelah SPM diterima oleh BUD. Prosedur penerbitan SP2D UP adalah :

a. Pengguna Anggaran menyerahkan SPM kepada Kuasa BUD

b. Kuasa BUD meneliti kelengkapan SPM yang diajukan

c. Apabila SPM dinyatakan lengkap Kuasa BUD menerbitkan SP2D paling lambat 2 hari kerja sejak diterimanya pengajuan SPM.

d. SP2D diserahkan kepada Bank dan Pengguna Anggaran

e. Kuasa BUD sendiri harus mencatat SP2D dan Nota Debet (dari Bank) pada dokumen penatausahaan, yang terdiri dari Buku Kas Penerimaan, Buku Kas Pengeluaran

f. Pengguna Anggaran menyerahkan SP2D kepada Bendahara Pengeluaran

g. Bendahara mencatat SP2D pada Dokumen Penatausahaan, yang terdiri dari BKU pengeluaran, Buku Pembantu Simpanan Bank, Buku Pembantu Pajak, Buku Pembantu Panjar, Buku rekapitulasi pengeluaran perincian objek

h. Apabila SPM dinyatakan tidak lengkap, Kuasa BUD menerbitkan surat penolakan penerbitan SP2D paling lambat 1 hari kerja sejak SPM diterima

i. Surat Penolakan penerbitan SP2D ini diserahkan kepada Pengguna Anggaran agar dilakukan penyempurnaan SPM. Kemudian diserahkan kembali kepada Kuasa BUD untuk diteliti.

5. Penerbitan Surat Pertanggungjawaban ( SPJ )

Surat Pertanggungjawaban ( SPJ ) merupakan dokumen yang menjelaskan penggunaan dari dana-dana yang dikelola oleh Bendahara Pengeluaran. SPJ juga merupakan laporan keuangan yang dihasilkan dari Bendahara Pengeluaran. Prosedur penerbitan SPJ adalah :

a. Bendahara Pengeluaran melakukan pencatatan bukti-bukti pembelanjaan dana UP

b. Dari proses pencatatan ini dihasilkan dokumen yaitu Buku Kas Umum Pengeluaran, Buku Pembantu Pengeluaran per rincian objek, Buku Pembantu Kas Tunai, Buku Pembantu Simpanan / Bank, Buku Pembantu Panjar, Buku Pembantu Pajak.

c. Berdasarkan 6 dokumen tersebut ditambah dokumen SPJ Pengeluaran Pembantu yang dibuat oleh Bendahara Pengeluaran Pembantu, Bendahara Pengeluaran membuat SPJ Pengeluaran. Dokumen SPJ yaitu Buku Kas Umum, Ringkasan pengeluaran per rincian objek disertai bukti-bukti yang sah, Bukti atas penyetoran PPN / PPh, Register penutupan kas. 
d. Bendahara pengeluaran menyerahkan SPJ Pengeluaran kepada PPK SKPD. Bendahara Pengeluaran juga harus menyerahkan SPJ Pengeluaran kepada BUD paling lambat tanggal 10 bulan berikutnya.

e. PPK SKPD memverifikasi SPJ Pengeluaran.

f. Apabila disetujui, maka PPK - SKPD menyampaikan SPJ Pengeluaran kepada Kepala SKPD paling lambat tanggal 10 bulan berikutnya

g. Kepala SKPD mengesahkan SPJ Pengeluaran

h. Kepala SKPD menyerahkan Surat Pengesahan SPJ kepada Bendahara Pengeluaran.

\section{Penggunaan Uang Persediaan}

Uang Persediaan (UP) adalah sejumlah uang tunai yang disediakan untuk belanja operasional sehari-hari dari SKPD yaitu untuk belanja barang dan jasa, UP tidak bisa digunakan untuk belanja modal ataupun belanja honorarium. Penggunaan UP menjadi tanggung jawab dari Bendahara Pengeluaran. Besarnya UP tergantung pada kebijakan daerah. Misalnya jika ada salah satu bidang di BAPELITBANGDA Kota Manado akan menyewa Bus maka bidang ini akan melapor kepada Pengguna Anggaran dalam hal ini yaitu Kepala BAPELITBANGDA kemudian akan didisposisi kepada Bendahara Pengeluaran, jika jenis belanjanya sesuai maka setelah mendapat perintah dari Pengguna Anggaran maka Bendahara Pengeluaran akan memberikan dana untuk keperluan dari bidang tersebut dengan tanda terima dan setelah itu bidang tersebut harus memberikan bukti nota/kwitansi dari kegiatan yang dilakukan serta bukti foto dari kegiatan tersebut.

\section{Prosedur Ganti Uang (GU)}

1. Pengajuan Surat Permintaan Pembayaran (SPP-GU)

SPP-GU digunakan untuk mengganti UP yang sudah terpakai. Prosedur pengajuan SPPGU adalah sebagai berikut.

a. Pengguna Anggaran yakni Kepala BAPELITBANGDA Kota Manado menyerahkan SPD kepada Bendahara dan PPK-SKPD

b. Berdasarkan SPD dan SPJ, Bendahara membuat SPP-UP beserta dokumen lainnya yang terdiri dari Surat Pengantar SPP-GU, Ringkasan SPP-GU, Rincian SPP-GU, Surat Pengesahan SPJ atas penggunaan dana SPP-GU sebelumnya, Salinan SPD, Surat pernyataan pengguna anggaran, Lampiran lain

c. Bendahara menyerahkan SPP-GU beserta dokumen lain kepada PPK-SKPD

d. PPK-SKPD meneliti kelengkapan dokumen SPP-GU berdasar SPD dan DPA-SKPD

e. SPP-GU yang dinyatakan lengkap akan dibuatkan Rancangan SPM oleh PPK-SKPD. Penerbitan SPM paling lambat 2 hari kerja sejak SPP-GU diterima.

f. Rancangan SPM ini kemudian diberikan PPK-SKPD kepada pengguna anggaran untuk diotorisasi

g. Jika SPP-GU dinyatakan tidak lengkap, PPK-SKPD akan menerbitkan surat penolakan SPM. Penolakan SPM paling lambat 1 hari kerja sejak SPP-GU diterima

h. Surat penolakan penerbitan SPM diberikan kepada Bendahara agar bendahara melakukan penyempurnaan SPP-GU. Kemudian diserahkan kepada PPK-SKPD untuk diteliti kembali.

2. Penerbitan Surat Perintah Membayar (SPM-GU) Prosedur pengajuan SPM-GU adalah sebagai berikut.

a. Pengguna Anggaran yakni Kepala BAPELITBANGDA Kota Manado menyerahkan SPD kepada PPK SKPD dan Bendahara

b. Berdasarkan SPD dan SPJ, bendahara membuat SPP-GU beserta dokumen lainnya, yang terdiri dari Surat Pengantar SPP-GU, Ringkasan SPP-GU, Rincian SPP-GU, Surat Pengesahan SPJ atas penggunaan dana SPP-GU sebelumnya, Salinan SPD, Surat Pernyataan Penggunaan Anggaran, Lampiran lain

c. Bendahara menyerahkan SPP-GU beserta dokumen lainnya kepada PPK SKPD 
d. PPK SKPD meneliti SPP GU berdasar SPD dan DPA-SKPD

e. Apabila SPP-GU dinyatakan lengkap maka PPK SKPD membuat Rancangan SPM, paling lambat 2 hari kerja sejak SPP diterima

f. PPK SKPD menyerahkan SPM kepada Pengguna anggaran untuk diotorisasi

g. Jika SPP-GU dinyatakan tidak lengkap, maka PPK SKPD akan membuat Surat Penolakan Penerbitan SPM, paling lambat 1 hari kerja sejak SPP-GU diterima

h. Surat penolakan penerbitan SPM diberikan kepada Bendahara agar Bendahara melakukan penyempurnaan SPP-GU. Kemudian diserahkan kepada PPK SKPD untuk diteliti kembali.

3. Penerbitan Surat Perintah Pencairan Dana (SP2D-GU) Proses penerbitan SP2D-GU adalah sebagai berikut.

a. Pengguna Anggaran yakni Kepala BAPELITBANGDA Kota Manado menyerahkan SPM kepada kuasa BUD

b. Kuasa BUD meneliti kelengkapan SPM yang diajukan

c. Apabila SPM dinyatakan tidak lengkap, Kuasa BUD menerbitkan SP2D paling lambat 2 hari kerja sejak diterimanya pengajuan SPM

Kelengkapan dokumen untuk penerbitan SP2D-GU adalah sebagai berikut:

1. Surat pengesahan SPJ Bendahara Pengeluaran periode sebelumnya

2. Ringkasan pengeluaran perincian objek disertai bukti pengeluaran yang sah dan kelengkapan

3. Bukti atas penyetoran PPN/PPh

d. SP2D diserahkan kepada Bank dan Pengguna Anggaran

e. Kuasa BUD sendiri harus mencatat SP2D dan Nota Debet (dari bank) pada dokumen penatausahaan, yang terdiri dari Buku kas penerimaan, Buku kas pengeluaran

f. Pengguna anggaran menyerahkan SP2D kepada Bendahara

g. Bendahara mencatat SP2D pada Dokumen Penatausahaan, yang terdiri dari BKU Pengeluaran, Buku pembantu simpanan bank, Buku pembantu pajak, Buku pembantu panjar, Buku rekapitulasi pengeluaran perincian objek

h. Apabila SPM dinyatakan tidak lengkap, Kuasa BUD menerbitkan surat penolakan penerbitan SP2D paling lambat 1 hari kerja sejak SPM diterima

i. Surat penolakan penerbitan SP2D ini diserahkan kepada Pengguna anggaran agar dilakukan penyempurnaan SPM. Kemudian diserahkan kembali kepada Kuasa BUD untuk diteliti.

\subsection{Pembahasan}

BAPELITBANGDA kota Manado berdasarkan teori efektivitas telah melaksanakan

Sistem dan Prosedur pembentukan serta penggunaan Uang Persediaan ( UP ) secara efektif sesuai dengan Permendagri Nomor 13 Tahun 2006 dan perubahannya yang kedua Permendagri Nomor 21 Tahun 2011 tentang Pedoman Pengelolaan Keuangan Daerah.

Sebagaimana yang tertuang dalam Permendagri Nomor 13 tahun 2006 dan perubahannya yang kedua permendagri 21 tahun 2011, Sistem dan prosedur pembentukan dan penggunaan uang persediaan yang dilaksanakan oleh BAPELITBANGDA kota Manado sudah sesuai yang terdiri atas :

1. Pembentukan :

a. Penerbitan Surat Penyediaan Dana ( SPD )

b. Pengajuan Surat Permintaan Pembayaran Uang Persediaan ( SPP UP )

c. Penerbitan Surat Perintah Membayar Uang Persediaan ( SPM UP)

d. Penerbitan Surat Perintah Pencairan Dana ( SP2D )

e. Penerbitan Surat Pertanggungjawaban ( SPJ )

Sebagai langkah pertama dari kegiatan pengeluaran kas dilakukan berdasarkan Surat Penyediaan Dana ( SPD ) yang adalah dokumen yang dibuat oleh BUD yang menyatakan 
tersedianya dana untuk melaksanakan kegiatan sebagai dasar penerbitan SPP. Berdasarkan SPD yang diterima, bendahara pengeluaran mengajukan SPP kepada pengguna anggaran melalui PPK SKPD. Dalam hal dokumen SPP dinyatakan lengkap, pengguna anggaran akan menerbitkan SPM. Apabila dokumen SPP tidak lengkap maka akan diterbitkan surat penolakan SPM. Penyiapan SPM dilakukan oleh PPK-SKPD dan penandatanganan dilakukan oleh pengguna anggaran. SPM yang telah diterbitkan oleh pengguna anggaran diajukan kepada BUD untuk penerbitan SP2D. BUD berhak menolak pencairan dana apabila SPM yang diterbitkan oleh pengguna anggaran tidak memenuhi persyaratan yang ditetapkan. Berdasarkan SP2D tersebut bendahara dapat mencairkan dana pada bank yang tercantum dalam SP2D sehingga dasar pencairan dana di bank oleh bendahara pengeluaran adalah SP2D.

2. Penggunaan

Uang Persediaan digunakan untuk membiayai kegiatan operasional sehari-hari SKPD yaitu untuk belanja barang dan jasa dan membiayai pengeluaran yang tidak dapat dilakukan melalui mekanisme pembayaran LS. Uang Persediaan (UP) tidak bisa digunakan untuk belanja honorarium.

\section{Evaluasi Pelaksanaan Penerbitan Surat Penyediaan Dana ( SPD )}

Dokumen ini menyatakan tersedianya dana untuk melaksanakan kegiatan sebagai dasar penerbitan SPP UP. BAPELITBANGDA Kota Manado telah melaksanakan sesuai dengan Permendagri No 13 tahun 2006 dan perubahannya yang kedua permendagri No 21 tahun 2011 tentang Pedoman Pengelolaan Keuangan Daerah. Informasi dalam SPD menunjukkan secara jelas alokasi tiap kegiatan, dimana pihak yang terkait yaitu:

1. Kuasa BUD ( Bendahara Umum Daerah )

Dalam kegiatan ini, kuasa BUD mempunyai tugas menganalisa DPA SKPD BAPELITBANGDA Kota Manado yang ada di database, menganalisa anggaran kas pemerintah khususnya ri data per SKPD dan menyiapkan draft SPD.

2. PPKD ( Pejabat Penatausahaan Keuangan Daerah )

Dalam kegiatan ini, PPKD mempunyai tugas meneliti draft SPD yang diajukan kuasa BUD, melakukan otorisasi SPD dan menyerahkan SPD kepada Pengguna Anggaran / Kuasa Pengguna Anggaran.

3. Pengguna Anggaran

Dalam kegiatan ini, PA mempunyai tugas mengarsipkan SPD yang diterima.

\section{Evaluasi Pelaksanaan Pengajuan Surat Permintaan Pembayaran ( SPP )}

Bendahara pengeluaran berdasarkan SPD mengajukan Surat Pengantar SPP kepada pengguna anggaran / kuasa pengguna anggaran melalui Pejabat Penatausahaan Keuangan SKPD ( PPK SKPD ). Pengajuan SPP UP hanya dilakukan sekali dalam setahun pada awal tahun anggaran oleh BAPELITBANGDA Kota Manado, selanjutnya untuk mengisi saldo uang persediaan akan menggunakan SPP GU. Mekanisme ini sudah sesuai dengan Permendagri No 13 tahun 2006 dan perubahannya yang kedua Permendagri No 21 tahun 2011 tentang Pedomaan Pengelolaan Keuangan Daerah. Pihak yang terkait dengan pengajuan SPP yaitu :

1. Bendahara Pengeluaran

Dalam kegiatan ini, Bendahara Pengeluaran mempunyai tugas mempersiapkan dokumen SPP beserta lampiran-lampirannya dan mengajukan SPP kepada PPKSKPD.

2. PPK-SKPD

Dalam kegiatan ini, PPK-SKPD mempunyai tugas menguji kelengkapan dan kebenaran SPP yang diajukan bendahara pengeluaran. 


\section{Evaluasi Pelaksanaan Penerbitan Surat Perintah Membayar (SPM)}

BAPELITBANGDA Kota Manado menerbitkan SPM sejalan dengan ketentuan dalam Permendagri No 13 tahun 2006 dan perubahannya yang kedua Permendagri No 21 tahun 2011 dimana SPM dapat diterbitkan jika pengeluaran yang diminta tidak melebihi pagu anggaran yang tersedia dan didukung dengan kelengkapan dokumen sesuai peraturan perundangan sedangkan waktu pelaksanaan penerbitan SPM, diterbitkan paling lambat dua hari sejak SPP diterima. Apabila ditolak, dikembalikan paling lambat satu hari sejak SPP diterima. Penerbitan SPM adalah otoritas Pejabat Pengguna Anggaran ( PPA ). Dengan demikian tanda tangan dokumen SPM dilakukan oleh pengguna anggaran yang bersangkutan sebagai sebuah pernyataan penggunaan anggaran di lingkup SKPDnya. SPM yang telah ditanda tangani kemudian diajukan kepada bendahara umum daerah ( BUD ) sebagai otoritas yang akan melakukan pencairan dana. Pihak yang terkait sebagai berikut :

1. PPK SKPD

Dalam kegiatan ini, PPK SKPD memiliki tugas menguji SPP beserta kelengkapannya, membuat rancangan SPM atas SPP yang telah diuji kelengkapan dan kebenarannya dan mengajukannya ke Pengguna Anggaran, menerbitkan Surat Penolakan SPM bila SPP yang diajukan oleh Bendahara SKPD tidak lengkap, membuat Register SPM

2. Pengguna Anggaran

Dalam kegiatan ini, Pengguna Anggaran memiliki tugas mengotorisasi dan menerbitkan SPM, menandatangani SPM, mengotorisasi surat penolakan SPM yang diterbitkan PPK SKPD bila SPP yang diajukan bendahara SKPD tidak lengkap.

\section{Evaluasi Pelaksanaan Penerbitan Surat Perintah Pencairan Dana (SP2D)}

SP2D atau Surat Perintah Pencairan Dana adalah surat yang dipergunakan untuk mencairkan dana lewat bank yang ditunjuk setelah SPM diterima oleh BUD. Sesuai dengan ketentuan dalam Permendagri No 13 tahun 2006 dan perubahannya yang kedua Permendagri No 21 tahun 2011, SP2D adalah spesifik artinya satu SP2D hanya dibuat untuk satu SPM saja. BAPELITBANGDA kota Manado telah melaksanakan sesuai dengan Permendagri No 13 tahun 2006 dan perubahannya yang kedua Permendagri No 21 tahun 2011. SP2D tersebut ditransfer ke bendahara pengeluaran BAPELITBANGDA kota Manado. Adapun pihak yang terkait yaitu :

1. Kuasa BUD

Dalam kegiatan ini, Kuasa BUD memiliki tugas melakukan pengujian atas kebenaran dan kelengkapan SPM, mencetak SP2D, mengirimkan SP2D kepada bank dan pengguna anggaran, membuat register SP2D

2. Pengguna Anggaran

Dalam kegiatan ini, Pengguna Anggaran memiliki tugas menandatangani SPM

3. Bendahara Pengeluaran SKPKD

Dalam kegiatan ini, Bendahara Pengeluaran SKPKD memiliki tugas mencatat SP2D pada dokumen penatausahaan yang terdiri atas BKU Pengeluaran, Buku Pembantu Simpanan Bank, Buku Pembantu Pajak, Buku Pembantu Panjar, Buku Rekapitulasi Pengeluaran Perincian Objek.

\section{Evaluasi Pelaksanaan Penerbitan Surat Pertanggungjawaban Pengeluaran (SPJ)}

Sesuai dengan ketentuan dalam Permendagri No 13 tahun 2006 dan perubahannya yang kedua Permendagri No 21 tahun 2011, bendahara pengeluaran secara administratif wajib mempertanggungjawabkan penggunaan uang persediaan ( UP ) kepada kepala SKPD melalui PPK SKPD paling lambat 10 bulan berikutnya. Prosedur pertanggungjawaban yang dilakukan oleh bendahara BAPELITBANGDA kota Manado sudah sesuai dengan aturan yang berlaku, dimana pihak terkait yaitu :

1. Bendahara Pengeluaran 
Dalam kegiatan ini, Bendahara Pengeluaran memiliki tugas menguji kebenaran dan kelengkapan dokumen pertanggungjawaban, melakukan pencatatan bukti-bukti pembelanjaan dana dari UP pada dokumen Buku pengeluaran, Buku Pembantu Simpanan/Bank, Buku Pembantu Pajak, Buku Pembantu Panjar, dan Buku Pembantu Pengeluaran per Objek, melakukan rekapitulasi pengeluaran dan mencatatnya dalam SPJ yang akan diserahkan ke Pengguna Anggaran ( melalui PPK SKPD ) untuk disahkan.

2. PPK SKPD

Dalam kegiatan ini, PPK SKPD memiliki tugas menguji SPJ pengeluaran beserta kelengkapannya, meregister SPJ pengeluaran yang disampaikan oleh Bendahara pengeluaran dalam buku register penerimaan SPJ pengeluaran, meregister SPJ pengeluaran yang telah disahkan oleh Pengguna Anggaran ke dalam buku register pengesahan SPJ pengeluaran, meregister SPJ pengeluaran yang telah ditolak oleh Pengguna Anggaran ke dalam buku register penolakan SPJ pengeluaran.

3. Pengguna Anggaran

Dalam kegiatan ini, Pengguna Anggaran memiliki tugas menyetujui atau menolak SPJ pengeluaran yang diajukan oleh Bendahara

\section{Evaluasi Penggunaan Uang Persediaan}

Pengajuan Uang Persediaan (UP) hanya dilakukan setahun sekali oleh Kantor BAPELITBANGDA Kota Manado, selanjutnya untuk mengisi saldo Uang Persediaan (UP) akan menggunakan SPP-Ganti Uang (GU). Mekanisme ini sudah sesuai dengan Permendagri No. 21 Tahun 2011 Tentang Pedoman Pengelolaan Keuangan Daerah.

Sebelum menggunakan Uang Persediaan dalam kegiatan sehari-hari, Kantor BAPELITBANGDA Kota Manado mengajukan beberapa surat yaitu, Surat Penyediaan Dana (SPD), Surat Permintaan Pembayaran (SPP), Surat Perintah Membayar (SPM), Surat Perintah Pencairan Dana (SP2D), dan Surat Perintah Pertnggungjawaban (SPJ).

\section{Evaluasi Prosedur Ganti Uang (GU)}

Ganti Uang (GU) digunakan untuk mengganti UP yang telah terpakai, dimana UP tersebut dipertanggungjawabkan penggunaan uang. Mekanisme ini diajukan oleh Kantor BAPELITBANGDA Kota Manado ketika UP habis. Proses penerbitan GU sudah sejalan dengan Permendagri No.21 Tahun 2011 tentang Pedoman Pengelolaan Keuangan Daerah.

Pada saat uang persediaan telah terpakai, dilakukan pengisian kembali (penggantian) dengan melampirkan bukti-bukti pembayaran yang telah dilakukan. Untuk memperoleh penggantian, bendahara pengeluaran mengajukan permintaan penggantian uang melalui SPPGU, dengan catatan permintaan penggantian uang maksimal sebesar jumlah uang yang diterima melalui SP2D-UP. Permintaan penggantian uang dilakukan dengan melampirkan bukti-bukti pembayaran yang telah diotorisasi oleh pengguna anggaran, rincian pengeluaran, dan bukti-bukti pendukung. Permintaan uang melalui penggantian uang dapat dilakukan berulang-ulang selama pelaksaan anggaran.

Penerbitan dan pengajuan dokumen SPP-GU dilakukan oleh bendahara pengeluaran. Sedangkan verifikasinya dilakukan oleh PPK-SKPD. Berdasarkan SPP-GU yang telah diverifikasi, PPK-SKPD menyiapkan SPM-GU untuk ditandatangani oleh pengguna anggaran. Pengguna anggaran melalui bendahara pengeluaran menyerahkan SPM-GU kepada kuasa BUD untuk meneliti kelengkapannya. Bila SPM-GU dinyatakan lengkap maka kuasa BUD menerbitkan SP2D-GU paling lambat 2 hari kerja sejak diterima pengajuan SPM-GU. Berdasarkan SP2D bank melakukan pembayaran/pemindahbukuan kepada bendahara pengeluaran. 


\section{KESIMPULAN DAN SARAN}

\subsection{Kesimpulan}

1. Pelaksanaan sistem dan prosedur pembentukan serta penggunaan uang persediaan (UP) pada BAPELITBANGDA Kota Manado sudah efektif dan sesuai dengan Permendagri No 13 tahun 2006 serta perubahan keduanya yaitu Permendagri No 21 tahun 2011 mencakup fungsi yang terkait, dokumen yang digunakan, laporan yang dihasilkan dan uraian teknis prosedur Uang Persediaan.

2. Dalam pelaksanaan sistem dan prosedur pembentukan serta penggunaan uang persediaan ( UP ) pada BAPELITBANGDA Kota Manado telah didukung dengan dokumen-dokumen terkait seperti Surat Penyediaan Dana ( SPD ), Surat Permintaan Pembayaran ( SPP ), Surat Perintah Membayar ( SPM ), Surat Perintah Pencairan Dana ( SP2D ) dan Surat Pertanggungjawaban ( SPJ ) serta dokumen terkait lainnya.

3. Prosedur pembentukan serta penggunaan uang persediaan ( UP ) pada BAPELITBANGDA Kota Manado telah dilakukan sesuai dengan prosedur dimana ada pemisahan tugas yang jelas dan adanya pertanggungjawaban sesuai dengan Permendagri No 21 tahun 2011.

\subsection{Saran}

1. Sebaiknya dapat meningkatkan dan mempertahankan efektivitas pelaksanaan sistem dan prosedur pembentukan serta penggunaan uang persediaan ( UP ) pada BAPELITBANGDA Kota Manado dan diharapkan untuk tetap mengikuti peraturan yang berlaku jika terjadi perubahan peraturan.

2. Sebaiknya lebih banyak mengadakan sosialisasi dan bimbingan teknis terhadap sumber daya manusia yang telah ada khususnya di bidang akuntansi agar dapat meningkatkan kualitas sumber daya manusia sehingga akan berdampak positif pada pelaksanaan sistem dan prosedur pembentukan serta penggunaan uang persediaan (UP) pada BAPELITBANGDA Kota Manado.

3. Sebaiknya dapat meningkatkan kinerja dan disiplin pegawai dalam menjalankan tugas dan fungsi sebagai pelayan masyarakat agar dalam proses kinerja dapat berjalan sesuai yang diharapkan.

\section{DAFTAR PUSTAKA}

Al-Fawwas, M Torki. The Impact Of Government Expenditures on Economic Growth in Jordan (1980-2013). Published by Canadian Center Of Science and Education.

Agbonkhese, Abraham Oni. 2014. Impact Of Public Expenditure On The Growth Of Nigerian Economy. European Scientific Journal. Vol.10 No.28 ISSN: 1857-7881.

Bawiling, Cindy. September 2015. Evaluasi Penerpan Sistem Pengendalian Internal Pengeluaran Kas pada Kantor Pengadilan Agama Tondano. Jurnal Emba. Vol.3 No.3 Hal. 619-629

Bacthiar, Mukhlis, Iskandar. 2013. Akuntansi Pemerintahan. Jakarta. Salemba Empat.

Bungkaes, Risal Heri. 2013. Hubungan Efektifitas Pengadaan Program Raskin dengan Peningkatan Kesejahteraan Masyarakat di Desa Mamahan Kecamatan Gemeh Kabupaten Talaud. Journal ACTA DIURNA.

Dwi Ratmono, Solihin. 2015. Akuntansi Keuangan Daerah. UPP STIM YKPN

Egbetunde, Tajudeen. 2013. Public Expenditure and Economic Growth in Nigeria, Evidence From Auto-Regressive Distributed Lag Specification. Zagre International Review of Economics \& Business. 
Kapoh, Iren Tessa. Maret 2015. Evaluasi Pelaksanaan Sistem dan Prosedur Pengeluaran Kas Uang Persediaan Dinas Pariwisata dan Kebudayaan Provinnsi Sulawesi Utara, Jurnal Emba. Vol.3 No.1 Hal.1053-1062.

Lahay, Novita Olivia. September 2013. Analisis Pelaksanaan Sistem dan Prosedur Pengeluaraan Kas pada Dinas Pekerjaan Umum Provinsi Sulawesi Utara, Jurnal Emba. Vol. 1 No. 3 Hal. 508-518.

Lethulur, Maritce. Juni 2013. Evaluasi Sistem Akuntansi Penerimaan dan Pengeluaran Kas Barang Jaminan pada PT. Pegadaian (PERSERO) cabang Tuminting, Jurnal Emba. Vol.1 No.3 Hal.550-557.

Mamahit, Patricia. Desember 2014. Evaluasi Sistem Informasi Akuntansi Penerimaan dan Pengeluaran Kas Rawat Inap RSUP. PROF. DR. R. D. Kandou Manado, Jurnal Emba. Vol.2 No.4 Hal.537-545.

Mahmud, Rahmad. Juni 2016. Analisis Sistem dan Prosedur Pengeluaran Kas dengan Menggunakan Uang Persediaan pada Dinas Sosial Kota Manado, Jurnal Emba. Vol.4 No.2 Hal.692-702.

Moeleong, Lexy J. 2013. Metodologi Penelitian Kualitatif. Bandung. Remaja Rosdakarya.

Mulyadi, 2013. Sistem Akuntansi. Salemba Empat.

Ointu, Rizal. September 2016. Evaluasi Pelaksanaan Sistem dan Prosedur Pengeluaran Kas Uang Persediaan pada DPPKAD KAB. BOLAANG MONGONDOW SELATAN. Jurnal Emba. Vol.4 No.3 Hal.156-164.

Oulsvitra, Lasse. 2010. Public Sector Accounting and the International Standardization Process Of Presenting Financial Statements. University Of Tampere, Finland. Halduskultuur Administrative Culture II.

Onibala, Maharani. Juni 2014. Evaluasi Sistem dan Prosedur Akuntansi Pengeluaran Kas Belanja Langsung pada Dinas Pekerjaan Umum Kabupaten Minahasa, Jurnal Emba. Vol. 2 No. 2 Hal. 1691-1701.

Panambunan, Greivy. Maret 2016. Evaluasi Pengendaliaan Internal dalam Pelaksanaan Sistem dan Prosedur Pengeluaran Kas pada Dinas Koperasi dan UMKM Sulawesi Utara, Jurnal Emba. Vol.4 No.1 Hal.907-915.

Pontoh, Winston. 2013. Akuntansi Konsep dan Aplikasi. Halaman Moeka Publishing, Jakarta Barat.

Republik Indonesia, Peraturan Pemerintah Nomor 71 tahun 2010 tentang Standar Akuntansi Pemerintahan.

Republik Indonesia. Undang - Uundang Dasar 1945 pasal 35 ayat 5 tentang Pertanggungjawaban Keuangan Negara.

Republik Indonesia. Undang - Undang Nomor 34 tahun 1954 tentang Pemakaian gelar Akuntan

Republik Indonesia, Menteri Dalam Negeri Nomor 21 tahun 2011 tentang Pedoman Pengelolaaan Keuaangan Daerah.

Republik Indonesia. Permenkeu No 17/PMK01/2008 tentang Jasa Akuntan Publik.

Repblik Indonesia. Permenkeu No 476/KMK/01/1991 tentang Sistem Akntansi Pemerintahan Pusat

Saputra, Marco Andrew. September 2013. Analisis Penerapan Sistem dan Prosedur Pengeluaran Kas pada BPBD Sulawesi Utara. Jurnal Emba. Vol.1 No.3 Hal.3243.

Sanggelorang, M. M. Septiana. Juli 2015. Pengaruh Pengeluaran Pemerintah di Sektor Pendidikan dan Kesehatan terhadap Indeks Pembangunan Manusi di Sulawesi Utara. Jurnal Emba. Vol.15 No. 2 Hal.211-224.

Sugiyono, 2013. Metode Penelitian Kuantitatif, Kualitatif, dan R\&D. Bandung. Alfabeta. . 